\title{
Compliance with and response to hepatitis B vaccination in remaining quilombo communities in Central Brazil
}

\author{
Adesão e resposta à vacinação contra hepatite $B$ \\ em comunidades remanescentes de \\ quilombos no Brasil Central
}

\footnotetext{
${ }^{1}$ Departamento de Farmácia-Bioquímica, Universidade Federal de Mato Grosso do Sul, Campo Grande, Brasil.

2 Instituto Oswaldo Cruz,

Fundação Oswaldo Cruz, Rio de Janeiro, Brasil.

${ }^{3}$ Faculdade de Enfermagem,

Universidade Federal de

Goiás, Goiânia, Brasil.

4 Instituto de Patologia

Tropical e Saúde Pública, Universidade Federal de

Goiás, Goiânia, Brasil.

Correspondence R. M. B. Martins Instituto de Patologia Tropical e Saúde Pública, Universidade Federal de Goiás.

C. P. 131, Goiânia, GO

74605-050, Brasil.

rbringel@terra.com.br
}

\begin{abstract}
Compliance with and responses to the hepatitis $B$ vaccine were evaluated in remaining quilombo communities in Central Brazil. A total of 708 individuals who were susceptible to hepatitis B virus infection were invited to participate in the hepatitis $B$ vaccination program in eight communities. Although 567 (80\%) individuals received the first dose, only 198 (28\%) complied with the full vaccination scheme. Of 148 subjects who agreed to be tested for anti-HBs, 123 (83.1\%; 95\%CI: 75.9-88.6) responded to the vaccine. A geometric mean titer of 512mIU/mL (95\%CI: 342.5-765.3) was found. Male sex and older age were independently associated with non-response. Additional health education programs and alternative hepatitis $B$ vaccine schedules are needed to improve the vaccination coverage in these communities in Central Brazil.
\end{abstract}

Hepatitis B Virus; Hepatitis B Vaccines; African Descendants

\author{
Ana Rita C. Motta-Castro ${ }^{1}$ \\ Selma A. Gomes 2 \\ Clara F. T. Yoshida 2 \\ Juliana C. Miguel 2 \\ Sheila A. Teles 3 \\ Regina M. B. Martins ${ }^{4}$
}

\section{Introduction}

Worldwide, there are approximately two billion people with serological evidence of hepatitis $B$ virus (HBV) exposure, and of these, more than 350 million are chronic carriers. These chronically infected individuals are at high risk of liver cirrhosis and hepatocellular carcinoma, mainly in the developing world, such as sub-Saharan Africa where the prevalence of HBV carriers exceeds $8 \%$. HBV infection is commonly diagnosed by the presence of hepatitis B antigen (HBsAg), which indicates acute or chronic infection. Antibodies to the hepatitis B core antigen (anti-HBc), another marker for HBV infection, appear in the acute phase of infection and persist for an indefinite time after virus clearance. The presence of antibodies against HBsAg (anti-HBs) is a marker of recovery and immunity. Anti-HBs coexisting with anti-HBc usually indicates a previous $\mathrm{HBV}$ infection, and anti-HBs as the only marker indicates immunity through the hepatitis $B$ vaccination 1 .

The hepatitis B vaccination is the most effective strategy to prevent HBV infection. Safe and effective vaccines against HBV infection have been available since 1982. In 1991, the World Health Organization recommended that the hepatitis B vaccination should be adopted by national immunization programs in all countries 1 . Brazil included the hepatitis B vaccine into childhood immunization schemes in 1998. Additionally, 
healthcare workers and other groups with risk factors for acquiring HBV infection have been vaccinated 2 . More recently, HBV vaccination has been recommended and offered free of charge to all individuals under the age of 20 .

The Brazilian population is largely made up of mixed European, African and Amerindian decent. African individuals were introduced to Brazil by slave traders. Some of them escaped from gold mines or farms, settling in remote valleys to escape their masters. These runawayslave descendants stayed in communities, called quilombos. Nowadays, there are more than 700 small villages (although less than 50 have been officially granted their land so far) whose history and tradition allows them to be identified as Remaining Quilombos. In a previous investigation, we found a high prevalence of HBV infection markers in some quilombo communities in Central Brazil (reaching $42.4 \%$ and $7.4 \%$ for anti$\mathrm{HBc}$ and HBsAg, respectively, in the Furnas dos Dionísios community) and a low rate of hepatitis B vaccination $(9.1 \%)$. In addition, family history of hepatitis and sexual activity besides increased age were statistically associated with HBV infection in that population 3 .

Those data strongly encouraged hepatitis B vaccination in remaining quilombo communities in Central Brazil. Initially, we conducted an informative education program regarding hepatitis $B$ and its prevention emphasizing the importance of hepatitis B vaccination in eight communities, and in February 2003, with the support of the Public Health authorities of the State of Mato Grosso do Sul, we started a vaccination campaign against hepatitis B in these communities, which provided a singular opportunity to evaluate the compliance with and the response to the recombinant $\mathrm{HBV}$ vaccine in these remaining quilombo communities.

\section{Material and methods}

\section{Study population}

A total of 708 individuals, who were previously identified as susceptible to HBV infection (defined as serological negative for HBsAg, anti$\mathrm{HBc}$, and anti-HBs markers) were invited to participate in the hepatitis B vaccination program in eight quilombo remnant communities in the State of Mato Grosso do Sul, Central Brazil. Seven communities under study were in rural areas: Furnas dos Dionísios ( $n=156)$, Jaraguari county; Furnas da Boa Sorte $(\mathrm{n}=121)$, Corguinho county; Malaquias ( $=74)$, Camapuã county; Jerônimos $(n=61)$, Terenos county; São Miguel
( $\mathrm{n}=45)$, Maracaju county; Furnas dos Baianos ( $\mathrm{n}=36$ ), Aquidauana county and Quintinos $(n=27)$, Pedro Gomes county. Subjects from these rural areas did not have adequate environmental sanitation facilities like sewage systems or tap water. The average household had 4.7 members, living in a very simple house with 3 or 4 rooms, which generally included at least one bedroom. They lived simply on subsistence agriculture or cattle-raising. The urban community, called São Benedito $(n=188)$, is located in the periphery of Campo Grande city, where sanitation conditions are still poor. Figure 1 shows the geographical location of these communities.

The protocol used in this present study was approved by the Ethical Committee of the Federal University of Mato Grosso do Sul. Informed consent was obtained from all participants. The studied population ranged in age from 2 to 95 years (mean age of 24.8 ), with $45 \%$ male subjects and $55 \%$ female. All reported a family income lower or equal to US\$100 per month, and the majority $(60.1 \%)$ was illiterate.

\section{HBV vaccination and anti-HBs quantification}

Among those who received the three doses (20 $\mu$ g for adults and $10 \mu \mathrm{g}$ for children at intervals of 0,1 and 6 months) of the hepatitis B vaccine (Engerix B, GlaxoSmithKline Biologicals, Rixensart, Belgium), blood samples were collected around 45 days after the last vaccine dose. Quantitative anti-HBs antibody was determined by automatic analysis using the Microparticle Immunoenzymatic Test AxSYM Ausab (Abbott, Germany). Samples with anti-HBs $>1000 \mathrm{mIU} /$ $\mathrm{mL}$ were diluted 1:10 and re-tested. Seroprotection was defined as concentration of anti-HBs equal to or higher than $10 \mathrm{mIU} / \mathrm{ml}$. Individuals were classified as non-responders (anti-HBs less than $10 \mathrm{mIU} / \mathrm{mL}$ ), low-responders (anti-HBs: 10$100 \mathrm{mIU} / \mathrm{mL}$ ), and high-responders (anti-HBs more than $100 \mathrm{mIU} / \mathrm{mL}$ ).

\section{Data analysis}

Seroprotection rates and 95\% confidence intervals $(95 \% \mathrm{CI})$ were calculated. Chi-square or Fisher's exact test were used to evaluate the association between non-response to the hepatitis $B$ vaccine and socio-demographic characteristics. The estimated odds ratio (OR) in univariate analysis was analyzed subsequently by multiple logistic regression to identify possible confounders. Statistical significance was assessed at the 0.05 probability level in all analyses. The geometric mean titer (GMT) of anti-HBs was calculated with $95 \%$ CI. Statistical evaluations were per- 


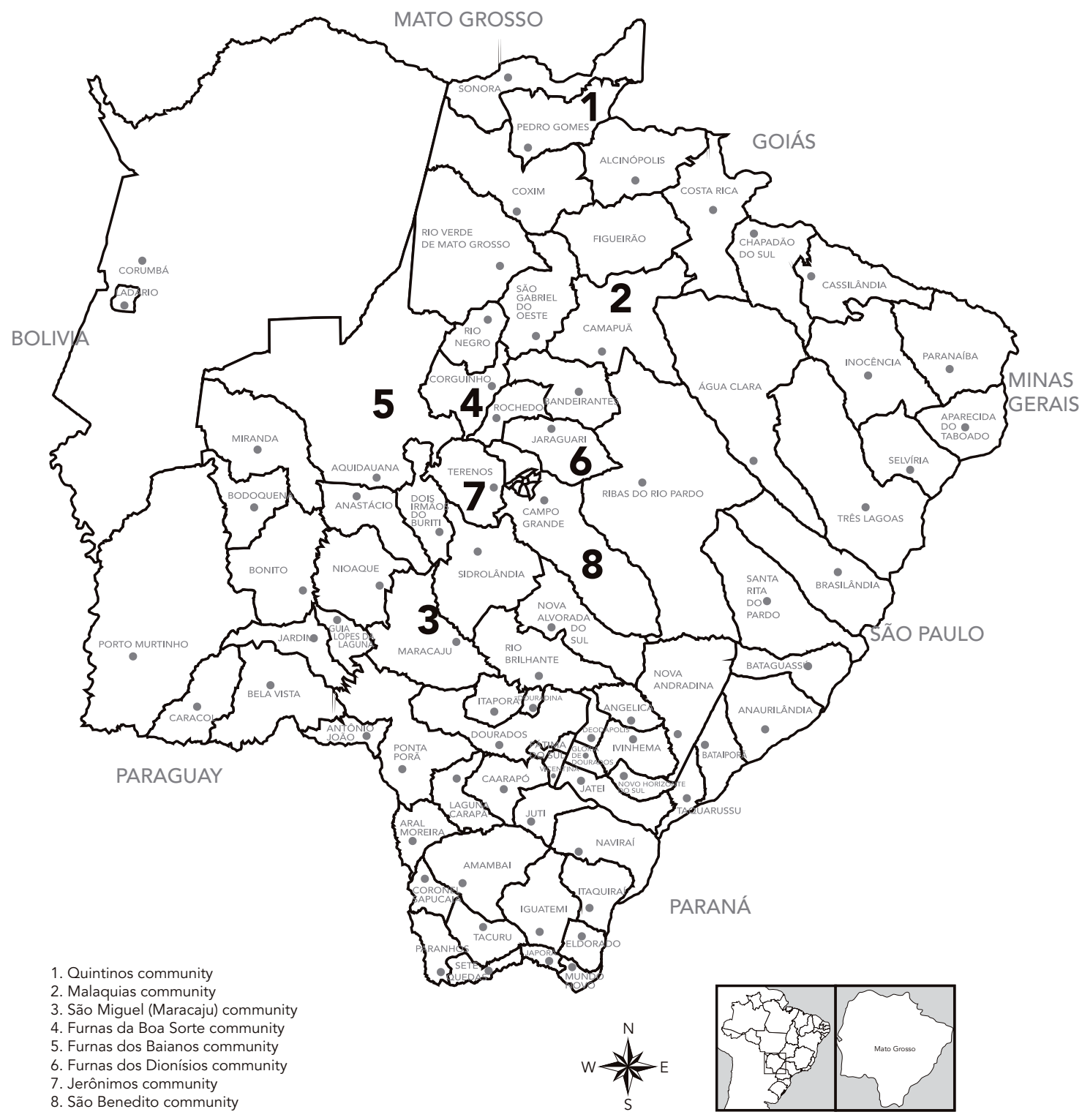

formed using SPSS version 11.0 (SPSS Inc., Chicago, USA).

\section{Results}

Of 708 individuals, 567 (80\%), 411 (58\%) and 198 (28\%) complied with the first, second and third doses of the hepatitis B vaccination, respectively.
Among those that received the full scheme, 148 (74.7\%) agreed to test for anti-HBs. There was no statistical difference between these groups regarding their socio-demographic characteristics ( $p$ > 0.05). 123 (83.1\%; 95\%CI: 75.9-88.6) responded to the HBV vaccine: 88 (59.5\%) as highresponders and $35(23.6 \%)$ as low-responders. Also, a GMT of 512mIU/mL (95\%CI: 342.5-765.3) was found. 
In order to identify socio-demographic factors associated with non-response to HBV vaccination, univariate and multivariate analyses were carried out. Two variables were independently associated with non-response in the studied population: male sex (Adjusted $\mathrm{OR}=2.6$; 95\%CI: 1.1-6.8) and age $\geq 40$ years (Adjusted OR = 3.7; 95\%CI: 1.4-9.7). Other factors such as alcohol drinking and smoking were more frequently found in non-responders when compared with those that responded to hepatitis B vaccine, but differences were not statistically significant.

\section{Discussion}

In this investigation, the hepatitis B vaccine was offered to all susceptible individuals in 8 remaining quilombo communities in Central Brazil after an education program to promote the health benefits of the vaccination. Although the majority complied with the first vaccine dose, only half of them did so with the second dose, and one-third with the full scheme. This situation has been observed in other groups, emphasizing the necessity for alternative hepatitis B vaccine schemes to maximize compliance. Indeed, in adolescents, a 2-dose regimen has been proposed when compliance with the HBV vaccine is poor ${ }^{4}$. There- fore, at least regarding adolescents in remaining quilombo communities, this regimen could be desirable since a low compliance (50\%) with the full scheme of HBV immunization was observed in individuals under the age of 20.

Anti-HBs titers greater than $10 \mathrm{mIU} / \mathrm{mL}$ were detected in $83.1 \%$ of the vaccinated subjects and a GMT of $512 \mathrm{mIU} / \mathrm{mL}$ was obtained, which were lower than those rates reported using recombinant vaccines 5 . On the other hand, non-response was associated with male sex and older age, confirming previous reports which have identified them as predictor variables of non-response to hepatitis B vaccine 5 . In fact, in individuals aged $\geq 40$ years (42/148), only $66.7 \%$ responded to the hepatitis B vaccine $(\mathrm{GMT}=90.5 \mathrm{mIU} / \mathrm{mL}$; 95\%CI: 44.9-182.2). Of these, the majority was low-responders. In contrast, $90 \%$ of individuals under the age of $40(11 / 106)$ achieved seroprotective levels of anti-HBs (GMT $=859.2 \mathrm{mIU} / \mathrm{mL}$; 95\%CI: 556.4-1,332.6). Among them, $80 \%$ were high-responders.

In conclusion, the present findings emphasize the urgent need for additional health education programs and alternative hepatitis $B$ vaccine schedules to improve the vaccination coverage in quilombo remnant communities, a reservoir of HBV in Central Brazil, an area considered to be of low hepatitis B endemicity.

\section{Resumo}

A adesão e resposta à vacina contra hepatite $B$ foram avaliadas em comunidades remanescentes de quilombos no Brasil Central. Um total de 708 indivíduos suscetíveis à infecção pelo vírus da hepatite B foi convidado para participar do programa de vacinação contra hepatite B em oito comunidades. Apesar de 567 (80\%) indivíduos terem recebido a primeira dose, somente 198 (28\%) aderiram ao esquema completo de vacinação. De 148 sujeitos que concordaram em dosar o anti-HBs, 123 (83,1\%; IC95\%: 75,9-88,6) responderam à vacina. Um título geométrico médio de $512 \mathrm{mUI} / \mathrm{mL}$ (IC95\%: 342,5-765,3) foi encontrado. Sexo masculino e idade foram independentemente associados com ausência de resposta. Programas adicionais de educação em saúde e esquemas alternativos de vacinação contra hepatite B são necessários para melhorar a cobertura vacinal nessas comunidades no Brasil Central.

Vírus da Hepatite B; Vacinas Contra Hepatite B; Afrodescendentes

\section{Contributors}

All six authors contributed to the conception and design of the study, drafting of the manuscript and to the final approval of the version to be published

\section{Acknowledgments}

Financial support was provided by the Brazilian Council for Scientific and Technological Development (CNPq). The authors wish to thank Edy F. Pereira, Gisele F. Bonfim, and Kátia M. B. Lima for their technical assistance. 


\section{References}

1. Custer B, Sullivan SD, Hazlet TK, Iloeje U, Veenstra DL, Kowdley KV. Global epidemiology of hepatitis B virus. J Clin Gastroenterol 2004; 38(10 Suppl 3): S158-68.

2. Ropero AM, Danovaro-Holliday MC, Andrus JK. Progress in vaccination against hepatitis $\mathrm{B}$ in the Americas. J Clin Virol 2005; 34 Suppl 2:S14-9.

3. Motta-Castro AR, Martins RM, Yoshida CF, Teles SA, Paniago AM, Lima KM, et al. Hepatitis B virus infection in isolated Afro-Brazilian communities. J Med Virol 2005; 77:188-93.

4. Cassidy WM, Watson B, Ioli VA, Williams K, Bird S, West DJ. A randomized trial of alternative two- and three-dose hepatitis B vaccination regimens in adolescents: antibody responses, safety, and immunologic memory. Pediatrics 2001; 107:626-31

5. Assad S, Francis A. Over a decade of experience with a yeast recombinant hepatitis B vaccine. Vaccine 1999; 18:57-67.

Submitted on $07 / \mathrm{May} / 2008$

Final version resubmitted on 14/Jul/2008

Approved on 15/Jul/2008 